\title{
PERSEPSI NASABAH TERHADAP PENERAPAN PRINSIP 5C DALAM PENYALURAN KREDIT USAHA RAKYAT (KUR) OLEH PT. BANK RAKYAT INDONESIA (PERSERO), TBK UNIT TOMBATU, MINAHASA TENGGARA
}

\author{
Maria Marlyn Monulandi \\ Joachim N. K. Dumais \\ Lyndon R. J. Pangemanan
}

\begin{abstract}
ABSRACT
This study aims to describe the perception of consumers towards the implementation of the principle of $5 C$ in loans of business credit (KUR) by Bank Rakyat Indonesia Tombatu Unit. Customer perception is the process of customers in selecting; managing and interpreting information received and furthermore will response to that information. 5C Principle are Character, Capacity, Capital, Condition, and Collateral. This study was conducted from March to June 2016. The implementation of research at PT. Bank Rakyat Indonesia (Persero) Tbk Tombatu Unit Southeast Minahasa Regency. The data used is primary data that interviewing the relevant customer and other customers using questionnaires, and secondary data obtained by dochmenting the data written by the BRI Tombatu Unit. The sampling method was convenience sampling method, where researchers have the freedom to choose any consumer who met as a sample. The number of respondents in this study was 75 respondents, namely the debtor / BRI customers Tombatu Unit. Analysis of the data used is descriptive analysis and Likert scale to describe the perception of consumers towards the implementation of the principle of $5 \mathrm{C}$ in lending business credit (KUR) by Bank Rakyat Indonesia. The research results showed that the perception of consumers towards the implementation of the principle of $5 C$ is good with a good interpretation that is $77.68 \%$ and that means customers lonsider application of the $5 \mathrm{C}$ principle to all customers is good, because then the loan funds can be returned, and on one side of the BRI as lender / credit will be able to advance its business and other side, BRI customers can apply for a loan back to a time in the future.
\end{abstract}

Keyword: 5C Principles, Distribution of Business Credit (KUR), Bank Rakyat Indonesia, Tombatu, Southeast Minahasa

\begin{abstract}
ABSTRAK
Penelitian ini bertujuan untuk mendeskripsikan persepsi nasabah terhadap penerapan prinsip 5C dalam penyaluran kredit usaha rakyat (KUR) oleh Bank Rakyat Indonesia Unit Tombatu. Persepsi nasabah merupakan proses nasabah dalam memilih, mengelola dan menginterpretasikan informasi yang diterima dan selanjutya akan dilakukan respons atas informasi tersebut. Prinsip 5C yaitu Character (Karakter/Watak), Capacity (Kapasitas), Capital (Modal), Condition (Kondisi), Collateral (Jaminan). Penelitian ini dilakukan dari bulan Maret sampai bulan juni 2016. Tempat pelaksanaan penelitian di PT. Bank Rakyat Indonesia (Persero) Tbk Unit Tombatu. Data yang digunakan adalah data primer yaitu melakukan wawancara kepada nasabah yang bersangkutan dan nasabah lain yang berkaitan dengan menggunakan kuesioner dan data sekunder diperoleh dengan cara domentasi data tertulis oleh pihak BRI Unit Tombatu. Metode pengambilan sampel adalah metode convenience sampling, dimana peneliti memiliki kebebasan untuk memilih siapa saja konsumen yang ditemui untuk dijadikan sampel. Jumlah responden dalam penelitian ini adalah 75 responden, yaitu debitur/nasabah BRI Unit Tombatu. Analisis data yang digunakan adalah analisis deskriptif dan pengukuran skala Likert yaitu untuk mendeskripsikan mengenai persepsi nasabah terhadap penerapan prinsip 5C dalam penyaluran kredit usaha rakya (KUR) oleh Bank Rakyat Indonesia Unit Tombatu. Hasil penelitian menunjukan bahwa persepsi nasabah terhadap penerapan prinsip 5C adalah baik dengan interpretasi baik yaitu 77,68 \% dan itu artinya nasabah menganggap penerapan prinsip 5C kepada semua nasabah adalah baik, karena dengan begitu maka dana pinjaman dapat dikembalikan, dan disatu sisi BRI sebagai pemberi pinjaman/kredit akan dapat memajukan usahanya dan disisi lain, nasabah BRI dapat mengajukan pinjaman kembali untuk waktu dimasa mendatang.
\end{abstract}

Kata kunci: Prinsip 5C, Kredit Usaha Rakyat (KUR), Bank Rakyat Indonesia (BRI), Tombatu, Minahasa Tenggara 


\section{PENDAHULUAN}

\section{Latar Belakang}

Peningkatan kesejahteraan rakyat merupakan salah satu tujuan pemerintah Indonesia, yaitu meningkatkan pendapatan dengan berbagai bidang usahanya. Salah satu cara yang dilakukan adalah dengan penyaluran modal untuk membantu meningkatkan jalannya usaha lewat pembiayaan melalui bank dengan menyalurkan kredit usaha rakyat (KUR). Modal merupakan sarana pendukung dalam kelangsungan suatu usaha, maka dengan ini pemerintah pun ikut serta membantu dangan pemberian kredit beruapa kredit usaha rakyat.

Menutur Fitriani D (2012) Perbankan merupakan bagian yang sangat penting dalam perekonomian, salah satunya sebagai lembaga intermediasi yang tugasnya menghimpun dana dari masyarakat dan menyalurkannya kembali dalam bentuk kredit. Menurut data Bank Indonesia, bahwa dunia perbankan Indonesia sejak tahun 2008 menyalurkan Kredit Modal Kerja lebih banyak dibandingkan kredit yang lain (Kredit Konsumsi dan Investasi).

Menurut Undang-undang RI No. 10 tahun 1998 tentang perbankan megatakan bahwa bank adalah badan usaha yang mengimpun dana dana dari masyarakat dalam bentuk simpanan dan menyalurkannya kepada masyarakat dan /atau bentuk-bentuk lainnya dalam rangka meningkatkan taraf hidup rakyat banyak.

Dunia perbankan di Indonesia telah menjadi tulang punggung perekonomian negara di mana sebagai salah satu pelaku utamanya, bank mempunyai peranan penting sebagai lembaga intermediary (perantara) antara pihak yang kelebihan dana dengan pihak yang kekurangan dana. Menurut Subegti (2010) Lembaga perbankan dalam perekonomian memilki fungsi yang straregik sebagai lembaga intermediasi bagi penyaluran danadari deficit unit ke surplus unit. Sector perbankan sanagtlah diregulasi oleh pemerintah atau Bank Sentral guna menghindari potensi risiko yang dapat menjadi boomerang bagi perekonomian nasioanl. .

Bank adalah salah satu jenis lembaga keuangan yang melaksanakan berbagai macam jasa, seperti memberikan pinjaman, mengedarkan mata uang, mengadakan pengawasan terhadap mata uang, bertindak sebagai tempat penyimpanan berkas, membiayai usaha perusahan-perusahan dan lain-lain. (Nazrian, 2012). Bank terdiri dari beberapa jenis yang di bagi dalam beberapa pokok baik dari segi fungsi yang terdiri dari bank sentral, bank umum, dan bank perkreditan rakyat (BPR), bank tabungan, bank pembangunan, bank desa. Dari segi kepemilikannya bank milik pemerintah, bank milik swasta nasional, bank asing, bank milik koperasi, bank campuran. Dari segi status, bank devisa dank bank non devisa. Ada juga dari segi penciptaan uang giral yaitu bank primer dan bank sekunder. Bank umum (Commercial Bank) memiliki peran yang sangat penting dalam menggerakan roda perekonomian nasional, karena lebih dari 95\% Dana Pihak Ketiga (DPK) perbankan nasional yang meliputi Bank Umum (Commercial Bank) yang terbagi dari Bank Rakyat Indonesia (BRI), Bank Mandiri, Bank Negara Indonesia (BNI), dan lain sebagainya. (Thamrin dkk, 2014)

Bank Rakyat Indonesia (BRI) merupakan salah satu bank yang telah ditunjuk oleh pemerintah dan dipercaya untuk melaksanakan kebijakan mengenai KUR dan menindaklanjuti kebijakan tersebut maka BRI mengeluarkan Surat Edaran Direksi Nose: S.09c - DIR/ADK/03/2010 atas Ketentuan Kredit Usaha Rakyat (KUR) Mikro (Deckiyanto 2013). Bank Rakyat Indonesia (BRI) merupakan salah satu lembaga keuangan perbankan yang menyediakan pembiayaan seperti KUR dan KUR-Mikro KKP-E yaitu produk kredit bank dengan skala mikro. Pemberian kredit oleh BRI pada hakikatnya di tujukan kepada masyarakat.

Kredit merupakan kemampuan untuk melaksanakan suatu pembelian atau mengadakan suatu pinjaman dengan suatu janji pembayarannya akandilakukan dan ditangguhkan pada suatu jangka waktu yang disepakati. (Kohler, dalam Respatiningsih 2011). Kredit adalah suatu penyertaan uang atau tagihan atau dapat juga barang yang menimbulkan tagihan tersebut pada pihak lain. Atau juga memberi pinjaman pada orang lain dengan harapan akan memperoleh suatu tambahan nilai dari pokok pinjaman tersebut yaitu berupa bunga sebagai pendapatan bagi 
pihak yang bersangkutan. (Pudjo Muliono dalam Respaningsih, 2011). Sebagian besar sumber dana operasional bank berasal dari simpanan masyarakat, untuk itu keberhasilan dan kegagalan bank dalam mengelola kredit akan berpengaruh pada rakyat banyak yang menyimpan uangnya di bank. Memberikan kredit bukan merupakan pekerjaan yang mudah karena proses pemberian kredit yang baik akan banyak menentukan kualitas kredit itu sendiri. (Amanda, 2015)

Kredit diberlakukan untuk membantu masyarakat dalam bidang usahanya berupa modal. Penyaluran kredit ini diperoleh dari dana yang dihimpun dari masyarakat yang berkelebihan dana untuk disimpan dibank dan kemudian disalurkan kepada yang membutuhkan dengan cara pemberian kredit, salah satunya adalah kredit usaha rakyat (KUR).

KUR ini disediakan hanya terbatas oleh bank-bank yang ditunjuk oleh pemerintah saja, yaitu : Bank Rakyat Indonesia (BRI), Bank Negara Indonesia (BNI), Bank Mandiri, Bank Syariah Mandiri, Bank Tabungan Negara dan Bank Bukopin. Penyaluran pola penjaminan difokuskan pada lima sektor usaha, yaitu : pertanian, perikanan dan kelautan, koperasi, kehutanan serta perindustrian dan perdagangan. KUR ini ditujukan untuk membantu ekonomi usaha rakyat kecil dengan cara memberi pinjaman untuk usaha yang didirikannya (Deckiyanto, 2013).

Penyaluran kredit oleh bank tidak lepas dari prinsip-prinsip kredit, dimana prinsip tersebut merupaka patokan apakah layak deberikan dana kredit atau tidak, karena baik pihak bank maupun nasabah harus berhati-hati dalam penyaluran kedit tersebut. Menurut Purnama (2013) sehubungan dengan penyaluran dana dalam bentuk kredit kepada masyarakat, bank harus dapat menjaga keseimbangan dimana selain untuk memperoleh keuntung bank juga harus dapat menjamin lancarnya pelunasan kredit yang telah disalurkan.

Prinsip kehati-hatian (prudential principle) merupakan prinsip yang menyatakan bahwa lembaga keuangan yang menjalankan fungsi dan kegiatan usahanya wajib menerapkan fungsi kehati-hatian dengan mengenal customer dalam rangka melindungi dana masyarakat yang dipercayakan masyarakat kepadanya. Penerapan prinsip kehati-hatian dapat dilihat dalam analisis pemberian kredit secara mendalam dengan menggunakan prinsip 5C (the five $C$ principle) yakni meliputi character (watak), capital (permodalan), capacity (kemampuan nasabah), condition of economy (kondisi ekonomi), collateral (agunan). (Anshori dalam Purnama, 2013).

Bank Rakyat Indonesia unit Tombatu menerapkan prinsip 5C kepada calon penerima kredit atau calon debitur dengan mengajukan pertanyaan-pertanyaan secara bertatap muka saat sedang melakukan pembicaraan (face to face).

Persepsi nasabah terhadap penerapan prinsip 5C dapat dilihat dari bagimana tanggapan respons nasabah terhadap penerapan prinsip 5C yaitu character (karakter/watak), capacity (kapasitas), capital (modal), condition (kondisi), dan collateral (jaminan).

\section{Rumusan Masalah}

Bagaimana persepsi nasabah terhadap penerapan prinsip $5 \mathrm{C}$ dalam penyaluran kredit usaha rakyat (KUR) oleh PT. Bank Rakyat Indonesia (Persero) Tbk Unit Tombatu?

\section{Tujuan}

Tujuan dari penelitian ini adalah untuk mendeskripsikan persepsi nasabah terhadap penerapan prinsip $5 \mathrm{C}$ dalam penyaluran kredit usaha rakyat (KUR) oleh PT. Bank Rakyat Indonesia (Persero) Tbk Unit Tombatu.

\section{Manfaat penelitian ini adalah dapat} menegetahui persepsi nasabah terhadap penerapan prinsip 5C dalam penyaluran kredit usaha rakyat oleh PT.Bank Rakyat Indonesia Unit Tombatu (Persero) Tbk dan menambah wawasan tentang kredit maupun prinsip-prinsip kredit terutama dalam kredit usaha rakyat (KUR).

\section{METODE PENELITIAN}

\section{Waktu dan Tempat Penlitian}

Penelitian ini dilakukan dari bulan Maret sampai bulan juni 2016. Tempat pelaksanaan penelitian di Bank Rakyat Indonesia (BRI) Unit Tombatu Kabupaten Minahasa Tenggara. 


\section{Metode Pengumpulan data}

Data yang dibutuhkan dalam penelitian ini adalah menggunakan data primer dan sekunder. Pengumpulan data primer diperoleh dengan mengadakan wawancara kepada nasabah yang bersangkutan dan nasabah lain yang berkaitan menggunakan kuesioner, juga dilakukan pengamatan terhadap beberapa prinsip sesuai kebutuhan.

Pengumpulan data sekunder berupa data tentang perkreditan yang diperoleh dengan cara dokumentasi data tertulis oleh pihak Bank Rakyat Indonesia (BRI) unit Tombatu.

\section{Metode Pengambilan Sampel}

Metode pengambilan sampel dalam penelitian ini adalah metode convenience sampling, dimana peneliti memiliki kebebasan untuk memilih siapa saja konsumen yang ditemui untuk dijadikan sampel (Kuncoro, 2012 ; Sunyoto, 2014). Untuk menghitung besarnya sampel digunakan rumus menurut Marzuki dalam Sunyoto (2014) sebagai berikut :

$$
\begin{aligned}
& n=\frac{\mathrm{N}}{\mathrm{N}\left(\mathrm{d}^{2}\right)+1} \\
& \text { Keterangan: } \\
& \mathrm{N}=\text { Jumlah populasi (semua konsumen kredit } \\
& \mathrm{n}=\text { Jumlah Sampel yang digunakan } \\
& \mathrm{d}=(1-\text { tk. Ketepatan ) } \\
& \text { Tingkat ketepatan yang digunakan adalah sebesar } \\
& 0.90 \\
& n=\frac{300}{300\left(0.1^{2}\right)+1} n=\frac{300}{3+1} n=\frac{300}{4}=75 \\
& \mathrm{~N}=300 \\
& \mathrm{~d}=0.1 \\
& \mathrm{n}=75
\end{aligned}
$$

Berdasarkan rumus maka jumlah populasi debitur KUR bank BRI Unit Tombatu ada 300 dan responden yang akan di gunakan dalam penelitian ini adalah 75 responden. Pengambilan sampel dalam penelitian ini adalah debitur kredit usaha rakyat (KUR) bank BRI Unit Tombatu.

\section{Konsep Pengukuran Variabel}

Pengukuran Persepsi Nasabah Terhadap Prinsip 5C yang digunakan dalam penyaluran kredit yaitu :
- Character (Karakter/Watak) : dilihat dari latar belakang debitur berupa kemampuan dalam membayar kewajiban dari debitur. Pengukuran variable character dibagi menjadi tiga instrument yaitu :

a. Pergaulan dengan sekitar tempat tinggal diukur dengan pergaulan penerima kredit dengan sekitar tempat tinggal berlangsung secara baik / tidak perna terjadi masalah

b. Reputasi/nama baik yang menyangkut dengan kejujuran diukur dengan kejujuran penerima kredit dengan rekan bisnis

c. Reputasi baik dalam kelancaran pembayaran pada kreditur, diukur dalam mengembalikan dana pinjaman kepada pihak kreditur tidak pernah terjadi tenggangan waktu atau keterlambatan pembayaran

- Capacity (Kapasitas): kemampuan dalam menjalankan usahanya. Pengukuran variabel capacity terbagi tiga yaitu :

a. Usaha memiliki arus kas yang baik diukur dengan usaha debitur yang memilki keuntungan yang baik

b. Hutang tidak melebihi asset yang ada pada debitur, diukur dengan jumlah pinjaman yang anda ajukan debitur kepada kreditur tidak melibihi jumlah seluruh asset yang anda miliki

c. Produk yang dihasilkan memiliki pemasaran yang baik, diukur dengan proses pemasaran produk usaha berjalan dengan baik, tidak ada halangan

- Capital (Modal) : Pengunaan modal debitur, dari mana modal sebelumnya, jumlah dana atau modal sendiri yang dimiliki oleh debitur. Pengukuran variabel capital dibagi tiga instrument, yaitu:

a. Modal yang dimiliki debitur, diukur dengan kepemilikan tempat usaha (milik sendiri)

b. Dana awal untuk usaha yang dimiliki, diukur dengan modal awal atau dana membuka usaha berasal dari milik sendiri

c. Memliki SDM dengan kemampuan yang mendukung, diukur dengan tenaga kerja / peralatan yang diguanakan untuk menjalakankan usaha yang memadai sehingga dapat memajukan usaha

- Condition (Kondisi) : melihat kondisi keuangan sekarang maupun masa yang akan datang yang dikaikan dengan prospek usaha dan volume penualan. kondisi perekonomian mempengaruhi kemampuan debitur untuk membayar kembali 
kewajiban. Pengukuran variabel condition di bagi tiga, yaitu:

a. Lokasi usaha debitur, diukur dengan letak lokasi usaha yang tidak terletak pada daereah yang rawan bencana

b. Usaha debitur sesuai dengan kebutuhan, diukur dengan usaha yang sesuai dengan kebutuhan masyarakat sekitar

c. Usaha debitur diterima dan menguasai pasar sekitar, diukur dengan usaha yang diterima oleh masyarakat sekitar dan dapat menguasai pasar dalam persaingan dengan yang lain

- Collateral (Jaminan) : jaminan yang miliki baik bersifat fisik maupun non fisik. yaitu status kepemilikan harta (rumah, kendaraan). Pegukuran variabel collateral dibagi tiga instrumen, yaitu :

a. Jenis Jaminan debitur, diukur dengan kesuluruhan asset yang dijadikan jaminan kepada pihak kreditur bersifat likuid (mudah dicaikan kembali tanpa kerugian)

b. Nilai jaminan, diukur berdasarkan nilai dari pada jaminan yang yang berikan kepada kreditur

c. Keaslian dan kepemilikan barang, diukur dengan jaminan benar-benar milik debitur dan memiliki bukti aslinya

\section{Metode Analisis Data}

Metode analisis data yang digunakan adalah analisis deskriptif yaitu mendeskripsikan mengenai persepsi nasabah terhadap penerapan prinsip 5C dalam penyaluran kredit usaha rakyat (KUR) oleh Bank Rakyat Indonesia (BRI) Unit Tombatu, dan pengukuran dengan skala Likert.

\section{Pengukuran Skala Likert}

Skala likert digunakan untuk mengukur sikap, pendapat, dan persepsi seseorang atau kelompok orang tentang fenomena seseorang (Soegiyono dalam Sunyoto, 2014). Pengukuran skala likert peneliti memberikan 15 pertanyaan dengan 75 responen yang kemudian jawaban tersebut ukur dengan kata-kata sebagai berikut :

$\begin{array}{rlll}\text { SB } & =\text { Sangat Baik } & \text { Skor }=5 & \\ \text { B } & =\text { Baik } & \text { Skor }=4 & \\ \text { CB } & =\text { Cukup Baik } & \text { Skor }=3 & \\ \text { TB } & =\text { Tidak Baik } & \text { Skor }=2 & \text { kor X }\end{array}$
jumlah responden

$$
\begin{array}{ll}
\text { S5 }=5 \times 75=375 & \text { S4 }=4 \times 75=300 \\
\text { S3 }=3 \times 75=225 & \text { S2 }=2 \times 75=150 \\
\text { S1 }=1 \times 75=75 &
\end{array}
$$

Jadi jumlah skor ideal dalam pengukuran skor adalah 375 dan yang terendah adalah 75 .

Interpretasi Nilai:

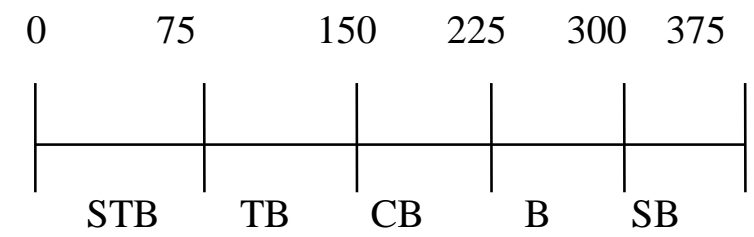

Cara perhitungan skor keseluruhan untuk mengetahui penerapan prinsip kredit : Jumlah skor seluruh kriteria = capaian jumlah skor $\mathrm{X}$ jumlah responden $\mathrm{X}$ instrumen pertanyaan

Untuk :

$$
\begin{aligned}
& \text { S5 }=5 \times 75 \times 15=5625 \\
& \text { S4 }=4 \text { X 75 X 15=4500 } \\
& \text { S3 }=3 \times 75 \times 15=3375 \\
& \text { S2 }=2 \times 75 \times 15=2250 \\
& \text { S1 }=1 \times 75 \times 15=1252
\end{aligned}
$$

Jadi jumlah skor ideal untuk keseluruhan pernyataan $=5625$ (Tinggi)

Jumlah skor terendah $=1252$

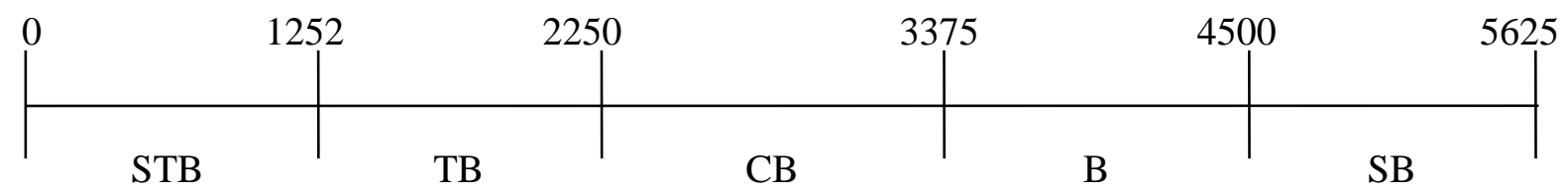


Analisis data yang digunakan merupakan analisis deskriptif yang yang di analisis dengan menggunakan skala pengukuran skala Likert. Adalah sebagai berikut:

(UMKM) dengan memberikan Persepsi Nasabah Terhadap Penerapan Prinsip 5Cb\#nga sebesar 9\% per tahun. BRI unit Tombatu

$\frac{\text { Jumlah Skor Hasil Pengumpulan Data }}{\text { Jumlah skor ideal (tertinggi) }} \times 100 \%$

Dengan interprestasi nilai:

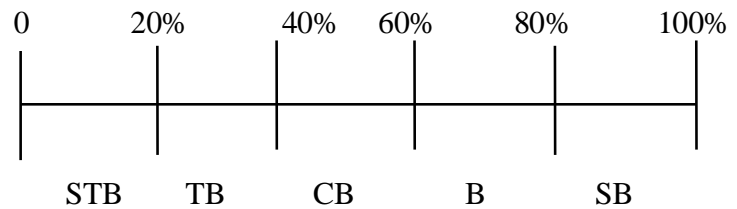

Keterangan kriteria inerprestasi skor penerapan prinsip 5C :

Angka 0\%-20\%= Sangat Tidak Baik

Angka 20\%-40\% = Tidak Baik

Angka 40\%-60\% = Cukup Baik

Angka 60\%-80\% = Baik

Angka 80\%-100\% = Sanagat Baik

\section{HASIL DAN PEMBAHASAN}

\section{Deskripsi Umum Tempat Penelitian}

Bank Rakyat Indonesia adalah salah satu bank milik pemerintah yang terbesar di Indonesia. Pada awalnya Bank Rakyat Indonesia (BRI) didirikan di Purwokerto Jawa Tengah oleh Raden Bei Aria Wiraatmadja. Lembaga tersebut berdiri tanggal 16 Desember 1895, yang kemudian dijadikan sebagai hari kelahiran BRI. Sejak 1 Agustus 1992 berdasarkan Undang-Undang Perbankan Nomor 7 tahun 1992 dan Peraturan Pemerintah RI Nomor 21 tahun 1992 status BRI berubah menjadi perseroan terbatas. Kepemilikan BRI saat itu masih $100 \%$ ditengah Pemerintah Republik Indonesia. Pada tahun 2003, Pemerintah IndonesiaMemutuskan untuk menjual $30 \%$ saham bank ini, sehingga menjadi perusahaan publik dengan nama resmi PT. Bank Rakyat Indonesia (Persero) Tbk yang masih digunakan sampai dengan saat ini. Lokasi penetilian dilakukan di PT. Bank Rakyat Indonesia (Persero) Tbk Unit Tombatu di Jl.
Lelengboto, Tombatu No.Telpon : 04313175607.

Kredit Usaha Raktat (KUR) oleh BRI unit Tombatu ditujukan kepada mereka yang memiliki usaha tergolong pada usaha mikro kecil mengengah (UMKM) dengan memberikan memberikan kredit kepada nasabah yang bergerak dibidang usaha pertanian berupa usaha tani hortikultura, perdagangan berupa jual beli kelapa, kopra, sembako, pedangan sayuran, dan kemudian usaha jasa berupa perbengkelan dan mebel.

\section{Penerapan prinsip 5C oleh Analis Kredit BRI Unit Tombatu}

Berdasarkan hasil survey langsung maka diketahui bahwa BRI unit Tombatu menerapkan prinsip 5C kepada Calon penerima kredit atau calon debitur dengan cara mengajukan pertanyaan-pertanyaan secara bertatap muka saat sedang melakukan pembicaraan (face to face). Pernyataanpernyataan yang diajukan yang berhubungan dengan dengan prinsip 5C, yaitu :

a. Bagaimana keuntungan yang diperoleh calon debitur dari usaha yang dikalukan

b. Bagaimana perbandingan pinjaman dengan asset yang dimilki ?

c. Bagimanan proses pemasaran usaha calon debitur bejalan ?

d. Bagaimana status kepemilikan tempat usaha dan modal membuka usaha ?

e. Bagaimana SDM yang dimiliki calon debitur dalam menjalankan usaha ?

f. Apakah jaminan yang akan diberikan, jumlah nilai jaminan dan apakah memiliki bukti asli kepemilikan ?

g. Bagaimana lokasi usaha calon debitur apakah rawan?

h. Apakah usaha calon debitur sesuai dengan kebutuhan dan diterima oleh masyarakat ?

i. Bagaimana reputasi calon debitur dengan masyarakat dan rekan bisnis ?

j. Bagaimana calon debitur mengembalikan dana/ melakukan penyetoran? 


\section{Karaktetistik Responden}

Jumlah responden dalam penelitian ini, berjumlah 75 responden peneriman Kredit Usaha Rakyat (KUR) pada Bank Rakyat Indonesia Unit Tombatu. 30 responden direkomendasikan dari bank dan 45 dari Kepala Desa yang ada dikecamatan Tombatu.

\section{Persepsi Nasabah terhadap PenerapaPrinsip5C}

\section{Rekapitulasi Kategori Penilaian}

\section{Character}

Character merupakan suatu keyakinan bahwa sifat atau watak dari orang-orang yang akan di berikan kredit benar-benar dapat di percaya, dilihat dari latar belakangnya berupa kemampuan dalam membayar kewajiban debitur.

Tabel 1 menunjukan bahwa terdapat 3 indikator persepsi nasabah terhadap prinsip character. Indikator dengan jumlah indeks tertinggi adalah pernyataan 2 yaitu 77,33\%, selanjutnya pernyataan 1 yaitu $72,53 \%$, dan pernyataan 3 yaitu $69,06 \%$.

Pergaulan dengan sekitar tempat tinggal memepengaruhi penialain karakter seseorang, karena apabila sering kali bermasalah dengan orang lain mengakibatkan perubahan pandangan. Angka indeks sebesar 72,53\%, sehingga interpretasi nilainya tergolong baik.
Artinya mereka mengganggap penerapan prinsip 5C oleh BRI Unit Tombatu kepada semua nasabah dari segi pergaulan di anggap baik, karena dengan pergaulan yang baik dengan sekitar tempat tinggal akan mampu membayar kembali dana pinjaman. Reputasi menyangkut kejujuran debitur dengan rekan bisnis merupakan hal yang penting, karena jujur kepada rekan bisnis itu berarti dapat bersikap jujur kepada BRI Unit Tombatu. Angka indeks indicator sebesar $77.33 \%$ tergolong baik (jujur). Artinya nasabah mengganggap penerapan prinsip $5 \mathrm{C}$ oleh BRI unit Tombatu adalah baik, karena dengan perlakukan yang jujur maka akan mampu membayar kembali dana pinjaman secara jujur. Menyangkut kelancaran pembayaran tagihan kepada kreditur yaitu BRI Unit Tombatu sangat penting karena penilaian karakter pembayaran yang tepat waktu akan menambah kepercayaan dari pihak kreditur, dan justru akan disarankan oleh BRI Unit Tombatu untuk melipat kembali dana untuk dipinjam, namun apabila sebaliknya terjadi tenggang waktu pembayaran maka kepercayaan pihak bank akan berkurang dan akan mengakibatkan kemacetan kredit yang kemudian memberatkan pihak debitur. Angka indeks kategori yaitu $69.06 \%$, tergolong baik. Artinya nasabah beranggapan bahwa penerapan prinsip 5C oleh BRI Unit Tombatu kepada nasabah dari segi kelancaran pembayaran adalah baik karena dengan demikian maka daa pinjaman dapat dikembalikan tanpa terjadi kemacetan kredit.

Tabel 1. Rekapitulasi Persepsi Nasabah Terhadap Character

\begin{tabular}{|c|c|c|c|c|}
\hline No & Pernyataan & Total Skor & Indeks penerapan $(\%)$ & Interpretasi \\
\hline 1 & $\begin{array}{l}\text { Pergaulan dengan } \\
\text { sekitar tempat tinggal }\end{array}$ & 272 & 72.53 & Baik \\
\hline 2 & $\begin{array}{lr}\text { Reputasi } & \text { yang } \\
\text { menyangkut } & \\
\text { kekujuran } & \text { dengan } \\
\text { rekan bisnis } & \end{array}$ & 290 & 77.33 & Baik \\
\hline 3 & $\begin{array}{l}\text { Kelancaran } \\
\text { pembayaran tagihan } \\
\text { kepada kreditur }\end{array}$ & 259 & 69.06 & Baik \\
\hline
\end{tabular}


Tabel 2. Rekapitulasi Persepsi Nasabah Terhadap Capacity

\begin{tabular}{llccc}
\hline No & \multicolumn{1}{c}{ Pernyataan } & Total Skor & $\begin{array}{c}\text { Indeks } \\
\text { penerapan (\%) }\end{array}$ & Interpretasi \\
\hline 1 & $\begin{array}{l}\text { Usaha yang dimiliki memiliki arus kas / keuntungan yang } \\
\text { baik }\end{array}$ & 289 & 77.06 & Baik \\
2 & $\begin{array}{l}\text { Asset yang dimiliki tidak melebihi jumlah hutang } \\
\text { pinjaman }\end{array}$ & 308 & 82.13 & Sangat Baik \\
3 & Pemasaran produk yang dihasilkan & 285 & 76 & Baik \\
\hline
\end{tabular}

Sumber : Diolah dari data primer, 2016

\section{Capacity}

Capacity yaitu kemampuan nasabah dalam bidang bisnis untuk menjalankan usahanya. Tabel 2 menunjukan terdapat 3 indikator persepsi nasabah terhadap prinsip capacity. Indicator dengan jumlah indeks tertinggi adalah pernyataan 2 yaitu $82,13 \%$, kemudian pernyataan 1 jumlah indeks $77,06 \%$ dan pernyataan 3 yaitu $76 \%$.

Apabila usaha bejalan dengan baik maka arus kas / keuntungan debitur pun ikut baik. Dengan demikian pembayaran/penyetoran dana kredit akan berjalan baik. Angka indeks yaitu $77.06 \%$ tergolong baik. Artinya nasabah menganggap penerapan $5 \mathrm{C}$ oleh BRI Unit Tombatu kepad semua nasabah dengan melihat arus kas/keuntungan adalah baik, karena dengan keuntungan yang baik maka dapat mengembalikan dana pinjaman kepada keditur.Berkaitan dengan asset yang dimiliki tidak melebihi hutang pinjaman memperoleh indeks prestasi tertinggi dari 3 kriteria pernyataan dengan jumlah sebesar $82.13 \%$ yaitu sangat baik. Artinya nasabah menganggap penerapan prinsip 5C dari segi asset yang dimiliki sangat baik, karena dengan jumlah pinjaman yang yang tidak lebih besar dari asset yang dimliki dapat dilihat bahwa akan mampu membayarkan kembali pinjaman tersebut. Dalam penelitian ditemukan bahwa jumlah pinjaman yang diberikan BRI Unit Tombatu dengan jumlah tertinggi Rp.25.000.000,- tidak sebanding dengan yang jumlah kekayaan debitur. Pemasaran produk usaha sangat penting dalam kelangsungan suatu usaha karena dengan pemasaran yang baik maka keuntungan juga akan baik. Indeks kriteria ini berjumlah $76 \%$, tergolong baik. Artinya nasabah menganggap penerpan 5C oleh BRI Unit Tombatu dari segi pemasaran produk usaha yang baik akan mampu mengembalikan dana pinjaman.

\section{Capital}

Capital merupakan penggunaan modal yang digunakan dalam menjalankan usaha berupa tempat, dana maupun sumber daya manusia (SDM). Tabel 3 terbagi 3 indikator persepsi nasabah terhadap capital. Indikator dengan jumlah tertinggi adalah pernyataan 2 denga jumlah $90.66 \%$, selanjutnya pernyataan 1 dengan jumlah indeks $89.6 \%$, kemudian pernyataan 3 dengan indeks $77.86 \%$. Kepemilikan tempat usaha merupakan modal untuk kelangsungan usaha. Angka indek berjumlah $89.6 \%$ tergolong sangat baik. Artinya nasabah menganggap penerapan prinsip 5C dari segi kepemikan tempat usaha kepada semua nasabah adalah sangat baik karena merupakan milik sendiri bukan disewa dan dengan begitu akan mampu mengembalikan dana pinjaman karena tempat usaha merupakan milik sendiri tanpa harus membayar sewa. Dana awal membuka usaha tidak sangat diperlukan untuk membeli segala keperluan usaha. Angka indeks 90.66\% termasuk dalam kategori sangat baik. Artinya nasabah menganggap penerapan $5 \mathrm{C}$ dilihat dari dana awal membuka usaha dengan dana milik sendiri sangat baik bukan pinjaman ataupun milik orang lain dan dengan demikian akan mampu mengembalikan dana pinjamanan. SDM yang mendukung dalam kelangsungan usaha berupa tenaga kerja dan peralatan yang memadai. Dengan SDM yang baik akan membantu kemajuan suatu usaha. Angka indeks $77.86 \%$ tergolong baik. Artinya nasabah mengganggap penerapan prinsip 5C oleh BRI Unit Tombatu kepada semua nasabah dengan melihat SDM adalah baik karena dapat dilihat apabila SDM baik maka akan mampu membayar dana pinjaman 


\section{Condition}

Condition adalah melihat kondisi keuangan sekarang maupun masa depan yang dikaitkan dengan prospek usaha dan volume penjualan. Tabel 4 terbagi 3 indikator persepsi nasabah terhadap condition. Indeks tertinggi terdapat pada pernyaataan 2 yaitu $81.6 \%$, selanjutnya pernyataan pernyataan 1 yaitu $79.46 \%$ dan kemudian pernyataan 3 yaitu $79.2 \%$

Usaha sesuai dengan kebutuhan masyarakat sekitar. Menjalakan usaha harus milhat kebutuhan masyarakat sekitar agar berjalan baik dan mudah untuk dijual dan memperoleh keuntungan. Angka Indeks 81,6\% adalah sangat baik, artinya nasabah menganggap penerapan prinsip 5C kepada semua nasabah dengan melihat usaha yang dijalankan sesuai kebutuhan adalah sangat baik, karena agar usaha lancar maka harus sesuai dengan kebutuhan masyarakat sekitar, dan dengan demikian dapat melihat apakah mampu membayar pinjaman atau tidak. tenggangan waktu untuk pembayaran dana pinjaman

Lokasi usaha terdapat pada daerah rawan bencan, dengan melihat kondisi maka lokasi berpengaruh dalam kelangsungan usaha. Apabila terkena pada daerah yang rawan seperti banjir dan longsor, maka akan menyulitkan nantinya bahkan menimbulkan kerurigan apabila terjadi bencana. Angka indek $79.46 \%$ adalah baik, artinya nasabah mengganggap penerapan prinsip $5 \mathrm{C}$ oleh BRI unit Tombatu kepada semua nasabah dengan melihat lokasi usaha adalah baik, karena dengan begitu piihak bank tidak ingin ada kejadian bencana yang nantinya akan menyebabkan tenggangan waktu pembayaran. Usaha diterima dan menguasai pasar dalam persaingan dengan yang lain. Menjalankan usaha harus bisa bersaing dengan yang lain dan diterima oleh masyarakat. Angka indeks $79.2 \%$ adalah baik, artinya nasabah menganggap dengan penerapan prinsip 5C kepada semua nasabah dari segi usaha diterima dan menguasai pasar adalah baik, karena dapat diketahui apabila diterima dan menguasai itu berarti pinjaman akan dapat dikembaikan.

\section{Collatera}

Collateral merupakan jaminan yang dimiliki debitur yaitu kepemilikan harta. Tabel 5 terbagagi 3 indikator persepsi nasabah terhadap collateral. Indeks tertingi ada pada pernyataan 1 yaitu sebesar $75.2 \%$, kemuadian pernyataan 3 indeks $69.33 \%$ dan selanjutnya pernyataan 2 yaitu $68.26 \%$.

Jenis jaminan bersifat likuid apabila dapat dengan mudah di cairkan kembali tanpa kerugian. Angka indeks yaitu $75.2 \%$ interpretasi nilai tergolong baik. Artinya nasabah mengganggap penerapn prinsip 5C oleh BRI unit Tombatu kepada semua nasabah dengan melihat sifat jenis jaminan apakah likuid adalah baik, karena dengan begitu dapat diketahui apabila suatu saat terjadi kredit macet maka jaminan yang diberikan dapat dicaikan kembali dengan mudah. Nilai jaminan merupakan jumlah nilai yang dberikan debitur kepada kreditur. Indeks angka yaitu $68.26 \%$ tergolong baik. Artinya debitur/nasabah menganggap penerapan prinsip 5C oleh BRI unit Tombatu kepada semua nasabah dari segi nilai jaminan adalah baik, karena dari jaminan yang ada dapat diketahui nilai jaminan dan dapat mendorong nasabah untuk melakukan pembayaran untuk mendapatkan kembali jaminan yang diberikan pada kreditur. Keaslian dpan kepemilikan barang. Memberikan jaminan melihat keaslian dan kepemilikan jaminan tersebut, apakah milik sendiri atau orang lain. Angka indeks yaitu $69.33 \%$ tergolong asli milik sendiri adalah baik. Artinya nasabah menganggap penerapan prinsip 5C oleh BRI unit Tombatu kepada semua nasabah dengan melihat keaslian jaminan adalah baik karena dapat diketahui apakah jaminan tersebut merupakan milik sendiri dan dengan begitu maka debitur akan berusaha membayar kembali dana pinjamn kepada kreditur.

\section{Rekapitulasi Keseluruhan Kategori}

Persepsi nasabah terhadap penerapan prinsip 5C berdasarkan hasil penilaian penuh seluruh kriteria diukur dengan 15 indikator pernyataan. Persepsi nasabah terhadap penerapan prinsip 5C oleh BRI unit Tombatu dengan hasil keseluruhan jumlah skor 4370 pada indeks tinggi yaitu $77.68 \%$ termasuk dalam interpretasi baik. Dari hasil analisis menggunakan skala Likert, maka diketahui bahwa angka indeks perepsi nasabah terhadap penerapan prinsip 5C berada pada interpretasi baik yaitu $77.6 \%$. Artinya nasabah mengaggap penerapan prinsip $5 \mathrm{C}$ kepada semua nasabah adalah baik, karena dengan penerapan tersebut nasabah akan dapat mengembalikan dana pinjaman sehingga disatu sisi BRI sebagai pemberi pinjaman/kredit akan dapat memajukan usahanya dan disisi lain, nasabah BRI dapat mengajukan pinjaman kembali untuk waktu dimasa mendatang 


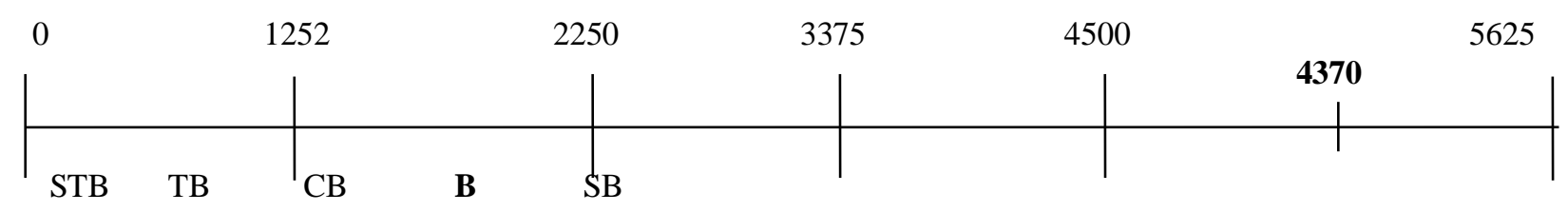

interprestasi nilai:

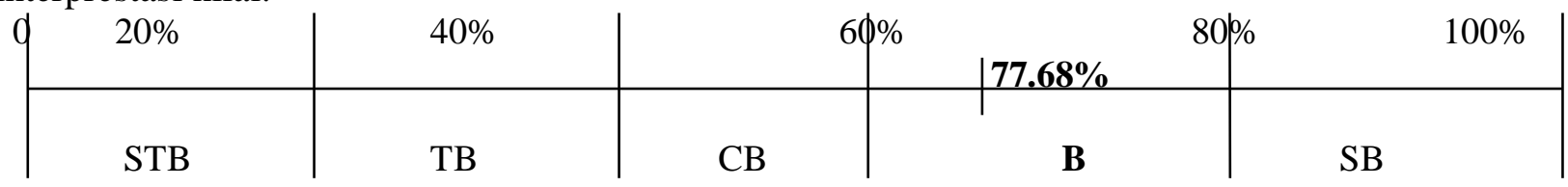

Tabel 3. Rekapitulasi Persepsi Nasabah Terhadap Capital

\begin{tabular}{llccc}
\hline No & \multicolumn{1}{c}{ Pernyataan } & Total Skor & $\begin{array}{c}\text { Indeks } \\
\text { penerapan (\%) }\end{array}$ & Interpretasi \\
\hline 1 & Kepemilikan tempat usaha & 336 & 89.6 & Sangat Baik \\
2 & Dana awa membuka usaha & 340 & 90.66 & Sangat Baik \\
3 & $\begin{array}{l}\text { Kemampuan SDM yang } \\
\text { kerja, peralatan) }\end{array}$ & 292 & 77.86 & Baik \\
\hline
\end{tabular}

Sumber : Diolah dari data primer, 2016

Tabel 4. Rekapitulasi Persepsi Nasabah Terhadap Condition

\begin{tabular}{llccc}
\hline No & Pernyataan & Total Skor & $\begin{array}{c}\text { Indeks } \\
\text { penerapan (\%) }\end{array}$ & Interpretasi \\
\hline 1 & Lokasi usaha terdapat pada daerah rawan bencana & 298 & 79.46 & Baik \\
2 & Usaha sesuai dengan kebuthan masyarakat sekitar & 306 & 81.6 & Sangat Baik \\
3 & $\begin{array}{l}\text { Usaha diterima dan menguasai pasar dalam } \\
\text { persaingangan dengan yang lain }\end{array}$ & 297 & 79.2 & Baik \\
\hline
\end{tabular}

Sumber : Diolah dari data primer, 2016

\section{Tabel 5. Rekapitulasi Persepsi Nasabah Terhadap Collateral}

\begin{tabular}{llccc}
\hline No & \multicolumn{1}{c}{ Pernyataan } & Total Skor & Indeks penerapan (\%) & Interpretasi \\
\hline 1 & Jenis jamiman bersifat likuid & 282 & 75.2 & Baik \\
2 & Nilai jaminan & 256 & 68.26 & Baik \\
3 & Keaslian dan kepemilikan barang & 260 & 69.33 & Baik \\
\hline
\end{tabular}

Sumber : Diolah dari data primer, 2016 


\section{KESIMPULAN DAN SARAN}

\section{Kesimpulan}

Persepsi nasabah terhadap penerapan prinsip 5C dalam penyaluran kredit usaha rakyat (KUR) oleh BRI Unit Tombatu adalah baik. Prinsip 5C yang dikategorikan sangat baik ada pada prinsip capacity yaitu asset yang dimiliki tidak melebihi hutang penjaman, capital yaitu kepemilikan tempat usaha dan dana awal membuka usaha, kemudian condition yaitu usaha sesuai kebutuhan masyarakt sekitar.

\section{Saran}

BRI Unit Tombatu tetap mempertahankan penerapan prinsip $5 \mathrm{C}$ yang telah dilakukan dan jika perlu ditingkatkan lebih baik dari yang sudah ada.

\section{DAFTAR PUSTAKA}

Astuti Tri, 2013. Pengaruh Persepsi Nasabah Tentang Tingkat Suku Bunga, Promosi dan Kualitas Pelayanan Terhadap Minat Menabung Nasabah (studi kasus pada BRI Cabang Sleman). Skripsi Progrm Studi Akuntansi Jurusan Pendidikan Akuntansi Fakultas Ekonomi Universirtas Negeri Yogyakarta.

Deckiyanto Firmansyah, 2013. Efektifitas Kebijakan Pemberian Kedit Usaha Rakyat (KUR) Mikro Berdasarkan Surat Edaran Direksi Nose: S.09cDIRADK/032010 Atas Keuntungan Kredit Usaha Rakyat (KUR) Mikro

(Studi di Bank Rakyat Indonesia Unit Sleko Cabang Madiun). Jurnal Kementrian Pendidikan dan Kebudayaan Fakultas Hukum Universitas Brawijaya

Eka Imania, 2013. Implikasi Kredit Pertanian Terhadap Pendapatan Petani (Studi kasus: Program Kredit Ketahanan Pangan dan Energi Pada Petani Tebu di Kabupaten Malang).Jurnal Ilmiah

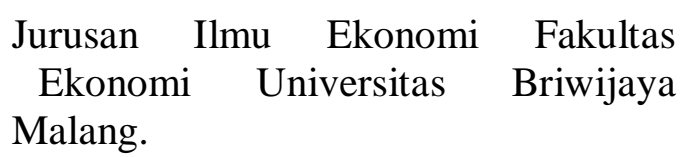

Fitriani D, 2012. Pengaruh Ratio Keuangan Bank Terhadap Penyaluran Kredit Modal Kerja Skripsi Fakultas Ekonomi Universitas Andalas

Kasmir, 2008. Manajemen Perbankan, edisi revisi delapan. Penerbit : Raja Grafindo Persada, Jakarta

Kotler P dan Amstrong G, 2000. Principle of marketing (pursyadin.terjemahan). Prince Hall International Inc. New Jersey

Kuncoro M, 2012. Metode Riset Untuk Bisnis dan Eknomi. Penerbit : Erlangga, Jakarta

Fahmi Irham, 2014. Manajemen Perkreditan. Penerbit : Alfabeta. Bandung

Muliyadi Nitisusastro, 2013. Perilaku konsumen dalam persepktif kewirausahaan. Alfabeta,CV.

Nazrian Adli, 2012. Studi Tentang Keputusan Nasabah dalam Menabung di Bank Sumut Cabang Usu Medan Metode Analytical Hierarchy Process. Jurnal Ekonomi dan Keuangan Vol 1, No. 1

Praiselia Amanda, 2015. Kajian Penyaluran Kredit Usaha Rakyat (KUR) Petanian Pada Bank BRI Kantor Cabang Tondano. Skripsi Jurusan Sosial Ekonomi Fakultas Petanian Universitas Sam Ratulangi Manado

Purnama Wahyu, 2015. Pelaksanaan Prinsip Kehati-hatian Dalam Rangka Pemberian Kredit Pada Bank BPD DIY Cabang Senopati. Skripsi Ilmu Hukum Fakultas Syari'ah dan Hukum Universitas Islam Negeri Sunan Kalijaga Yogyakarya 
Respatiningsih Hesti, 2011. Manajemen Kredit Usaha Mikro Kecil Dan Menengah (UMKM). Segmen. Jurnal Manajemen dan Bisnis No.1

Setiadi Nugroho, 2013. Perilaku Konsumen Penerbit: Kencana Prenada Media Group

Subegti Rangga, 2010. Determinasi Penyaluran Kredit Bank Umum Di Indonesia periode 2006-2009. Jurnal Keuangan dan Perbankan, Vol 14, No.3, 415-424

Sudaryanto, Raimun \& Wijayanti. R, 2013. Strategi Pemberdayaan UMKM Menghadapi Pasar Bebas Asean. Jurnal Badan akaebijakan Fiskal Kemenkeu RI

Sunyoto Danang, 2014.Praktik Riset Perilaku Konsumen. CAPS (center of aademic publishing services. Jl. Cempaka putih No.8. Yogyakarta)

Syofwan Ari, 2012. Peranan Kredit Usaha Rakyat Terhadap Pengembangan UKM di Kecamatan Gebang Kabupaten Langkat. Skripsi Fakultas Ekonomi Universitas Sumatera Utara
Thamrindan A \& Tantri F, 2014. Bank dan Lembaga Keuangan. Penerbit Rajawali. Jakarta

Wardhani Nurul, 2010. Pelaksanaan Pemberian Kredit Usaha Rakyat Pada Bank Rakyat Indonesia Unit Kurawasan Cabang Gombong. Skripsi Jurusan Ilmu Hukum Fakultas Hukum Universitas Sebelas Maret Surakarta

Wilardjo S, 2004. Pengertian Peran dan Perkembangan Bank Syaria'ah di Indonesia.Jurnal Value Added, Vol. 2, No. 1

-------- Undang-Undang Nomor 10 Tahun 1998 Pentang Perbankan, 2002. Jakarta: Diperbanyak oleh PT Raja Grafindo Persada. Jakarta

Kementrian Koordinator Bidang Perekonomian Republik Indonesia. 2015. Pemberdayaan UMKM dalam Paket Kebijakan Ekonomi September 2015. Surabaya 